\title{
Impact of stocking density on the rearing environment and growth performance of broiler chicken
}

${ }^{1}$ Asaniyan*, E. K. and ${ }^{2}$ Akinduro, V. O.

${ }^{I}$ Department of Animal Production and Health, Olusegun Agagu University of Science and Technology, P.M.B.353, Okitipupa. Ondo State, Nigeria.

${ }^{2}$ Department of Animal Science, College of Agriculture, Osun State University, P. M. B 4494, Osogbo. Osun State, Nigeria

Corresponding author : ekasaniyan@gmail.com; +2348035726703

Abstract

The consequence of high stocking density in commercial production of broiler chickens under the changing climate could predispose the chickens to adverse conditions. Therefore, this study was conducted to investigate the influence of stocking density on the rearing environment and performance of broiler chicken. Ninety (90) one day-old chicks of Arbor acre breed were used as experimental units in the trial that lasted eight (8) weeks. The birds were randomly assigned to three treatments of stocking densities 5, 10 and $15 \mathrm{birds} / \mathrm{m}^{2}$ with three replicates per treatment. The birds were raised in deep litter system bedded with woodshaving at $1 \mathrm{~m}^{2}$ per replicate. They were fed ad libitum with commercial broiler diets with drinking water supplied without restrictions. The meteorological data (Temperature and Relative Humidity) within the pen were obtained using the Maxims thermocron i-button Temperature and Humidity sensors and a stand-alone automated weather station was deployed outside the pen house which measured Temperature and Relative humidity parameters within the premises (Figure 1c), which were programmed to measure at 10 minutes sampling interval. Data collected were on daily ambient temperature and relative humidity, feed intake, water intake, weight gain and computed feed conversion ratio. The temperature of the broiler pens was found inversely related to its relative humidity across the treatments with relative fluctuations as the birds grow. Temperature within the pens (ambient temperature) increased with the stocking densities; stocking density $15 \mathrm{birds} / \mathrm{m}^{2}$ $\left(25.94 \pm 0.125^{\circ} \mathrm{C}-31.79 \pm 0.360^{\circ} \mathrm{C}\right)$ being the hottest while 5 birds $/ \mathrm{m}^{2}\left(25.47 \pm 0.136^{\circ} \mathrm{C}\right.$ $\left.31.43 \pm 0.353^{\circ} \mathrm{C}\right)$ was the least. Birds at stocking density of $5 \mathrm{birds} / \mathrm{m}^{2}(90.00 \mathrm{~g} / \mathrm{bird} /$ week $2197.78 \mathrm{~g} / \mathrm{bird} /$ week) performed better in terms of growth and followed by those of 10 birds $/ \mathrm{m}^{2}\left(95.00 \mathrm{~g} / \mathrm{bird} /\right.$ week - 2018.52g/bird/week). Stocking densities of $15 \mathrm{birds} / \mathrm{m}^{2}$ $(84.19 \mathrm{~g} / \mathrm{bird} /$ week $-1907.44 \mathrm{~g} / \mathrm{bird} /$ week) recorded the lowest weight gain. The combine influence of weather parameters (temperature and relative humidity) in bringing about growth of the birds diminishes as the stocking density increases. There was virtually no significant influence of the stocking densities on weekly mean temperature and relative humidity in the broiler chicken pens throughout the period of the study. Therefore, for eight weeks rearing period under any of the stocking density levels, fatality of weather modification could be prevented within the rearing environment through provision of adequate ventilation.

Keywords: Age, heat stress, poultry, ventilation, weather 


\section{L'Impact de la densité d'élevage sur l'environnement d'élevage et les performances de croissance des poulets de chair}

\section{Résumé}

La conséquence de la forte densité d'élevage dans la production commerciale de poulets de chair dans le climat changeant pourrait prédisposer les poulets à des conditions défavorables. Par conséquent, cette étude a été menée pour étudier l'influence de la densité d'élevage sur l'environnement d'élevage et les performances des poulets de chair. Quatrevingt-dix (90) poussins d'un jour de race 'Arbor acre' ont été utilisés comme unités expérimentales dans l'essai qui a duré huit (8) semaines. Les oiseaux ont été assignés au hasard à trois traitements de densités de peuplement de 5, 10 et 15 oiseaux / m2 avec trois répétitions par traitement. Les oiseaux ont été élevés dans un système de litière profonde recouvert d'un rasage de bois à $1 \mathrm{~m} 2$ par répétition. Ils ont été nourris ad libitum avec des régimes commerciaux pour poulets de chair avec de l'eau potable fournie sans restrictions. Les données météorologiques (température et humidité relative) à l'intérieur du stylo ont été obtenues à l'aide des capteurs de température et d'humidité 'Maximsthermocron i-button' et une station météorologique automatisée autonome a été déployée à l'extérieur de l'enclos qui mesurait les paramètres de température et d'humidité relative dans les locaux (Figure 1c), et ils ont été programmés pour mesurer à 10 minutes d'intervalle d'échantillonnage. Les données recueillies concernaient la température ambiante quotidienne et l'humidité relative, la consommation alimentaire, la consommation d'eau, le gain de poids et le taux de conversion alimentaire calculé. La température des enclos a été trouvée inversement proportionnelle à son humidité relative pendant les traitements avec des fluctuations relatives à mesure que les oiseaux grandissent. La température à l'intérieur des enclos (température ambiante) augmentait avec les densités de stockage ; densité de peuplement 15 oiseaux / m2 $\left(25,94 \pm 0,125^{\circ} \mathrm{C}-31,79 \pm 0,360^{\circ} \mathrm{C}\right)$ étant le plus chaud tandis que 5 oiseaux / $m 2\left(25,47 \pm 0,136^{\circ} \mathrm{C}-31,43 \pm 0,353^{\circ} \mathrm{C}\right)$ était le moins. Les oiseaux ayant une densité de peuplement de 5 oiseaux / $\mathrm{m} 2$ (90,00 g / oiseau / semaine - 2197,78 g / oiseau / semaine) ont obtenu de meilleurs résultats en termes de croissance et suivis par ceux de 10 oiseaux / m2 (95,00 g / oiseau / semaine - 2018,52 g / oiseau / semaine). Des densités de peuplement de 15 oiseaux / m2 (84,19 g/oiseau/semaine - 1907,44 g/oiseau/semaine) ont enregistré le gain de poids le plus faible. L'influence combinée des paramètres météorologiques (température et humidité relative) dans la croissance des oiseaux diminue au fur et à mesure que la densité d'élevage augmente. Il n'y avait pratiquement aucune influence significative des densités de peuplement sur la température moyenne hebdomadaire et l'humidité relative dans les enclos de poulets de chair pendant toute la période de l'étude. Par conséquent, pendant une période d'élevage de huit semaines, quel que soit le niveau de densité de peuplement, la mortalité due aux modifications climatiques pourrait être évitée dans l'environnement d'élevage grâce à une ventilation adéquate.

\section{Mots clés : âge, stress thermique, volaille, ventilation, météo}

\section{Introduction}

The commercial production of broiler chickens under intensive management is commonly at stocking densities higher than optimum stocking density of 5 birds per $\mathrm{m}^{2}$ reported by Asaniyan and Agbede (2012). The Increasing stocking density is an important management practice taken by 


\section{Asaniyan and Akinduro}

the poultry farmers to reduce the costs of poultry production (Estevez, 2007). Bird's welfare under a very high stocking densities may be impaired directly through physical restriction of the movement and indirectly through poor litter quality, high ammonia level and heat are also suggested to affect welfare (SCAHAW, 2000). Stocking density is a central issue of broiler welfare. It has been discovered that stocking density reduced the growth rate through its influence on air and litter quality by increasing the moisture content of the litter which enhances microbial activity, which in turn leads to increase of temperature and ammonia in broiler houses (Bessei, 2006). However, lowering stocking density without paying attention to the rearing environment may still compromise the welfare of broiler chicken. Controlling the environment (particularly temperature, humidity, air and litter quality) is crucial to broiler chicken welfare (Jones et al., 2005). The impact of the ambient condition may be beneficial or detrimental, depending on the extent of weather elements variations. The impact of weather elements may be expressed singly or in combinations; for instance, Bianca (1976) reported that low ambient temperature plus high air movement (cold) or high ambient temperature and high relative humidity plus solar radiation (heat) exert various effects on animal well-being, demonstrated in neuroendocrine, cardiorespiratory and behavioural responses. The concern for weather elements in recent years is due to the fact that they are not constant, but change continuously. Such changes affect the internal environment of birds, including the blood through the nervous and endocrine systems (Oladele et al., 2003). In the tropical environment, weather elements exert significant influence on domestic birds. Direct weather elements affecting birds include, especially, high ambient temperature and high relative humidity, resulting in severe heat stress. The report of Egbunike (1979) suggests that the effect of a hot environment on the body of birds depends not only on the nature of the microclimatic factors involved, but also on their intensity. Heat stress is very common and on the increase in the tropical and subtropical production of poultry chickens. It inflicts heavy economic losses on poultry production as a result of stunted growth (Sahin et al., 2001). In Nigeria, the combination of high ambient temperature and high relative humidity, reaching climax at the onset of the rainy season, constitutes extreme heat stress, which depresses the production of broiler and layer birds. Conversely, the low ambient temperature and low relative humidity, prevailing from November to February during the Harmattan season, especially in the morning and evening hours of the day, enhance egg and broiler production (Bannor and Ogunsan, 1987). Heat stress depresses growth rate and production as a result of a down-turn in voluntary feed intake in broilers (Sahin et al., 2001). Heat stress is a deterrent to successful and profitable poultry production (McNabb and King, 1993). The optimum ambient temperature range for poultry is $12-26^{\circ} \mathrm{C}$ (Plyaschenko and Sidorov, 1987). However, the ideal temperature for broilers is $10-22^{\circ} \mathrm{C}$ to get optimum body weight and $15-27^{\circ} \mathrm{C}$ for feed efficiency (Rama Rao et al., 2011). A temperature above $30^{\circ} \mathrm{C}$ represents a heat- stressed condition for birds and is one of the most common stressors that affect the production criteria in poultry (Rama Rao et al., 2011). Broiler heat loss is comprised of two components; latent heat loss and sensible heat. Latent heat loss is usually expressed as the amount of water evaporated from the broiler, referred to as "moisture production". Evaporation uses broiler heat to change 
water state from liquid to vapour. The evaporation takes place inside the broiler as water passes over the wet surfaces of its respiratory system. Sensible heat loss refers to heat dissipated through heat transfer from the broiler to the surrounding air. If the air is cooler than the broiler's surface temperature, heat flows from the broiler to the surroundings. If the air is warmer than the broiler's surface temperature, broilers will not be able to dissipate heat and heat stress will occur. Stress is of major concern for poultry industry because it exerts deleterious effects on different parameters like feed intake, feed conversion ratio, weight gain and so on (Pawan et al., 2012). Therefore, this study investigated stocking density influence on rearing environment and performance of broiler chicken.

\section{Materials and methods}

This study was carried out on the Poultry Unit of the Teaching and Research Farm, Joseph Ayo Babalola University, Ikeji Arakeji, Osun State, Nigeria; located at latitude $07^{\circ} 51^{\prime} \mathrm{N}$ and longitude $4^{\circ} 88^{\prime} \mathrm{E}$. Prior to the start of the experiment all chicks were individually weighed and randomly assigned to three groups of different stocking densities. Each pen was $1 \mathrm{~m}^{2}$. In each treatment, the chicks were kept in tagged pens under deep litter management system in a ventilated house. Ninety (90) day-old chicks of Arbor acre breed were used as experimental unit in the experimental trial that lasted eight (8) weeks. The birds were randomly assigned to three treatments of stocking densities S5, $\mathrm{S} 10$ and $\mathrm{S} 15$ of 5,10 and 15 birds $/ \mathrm{m}^{2}$ respectively with three replicates per treatments. The birds were raised in deep litter system bedded with wood-shaving litter. They were fed ad libitum with commercial broiler diets and drinking water supplied without restriction. The meteorological data (Temperature and Relative humidity) within the pen were obtained using the Maxims thermocron ibutton Temperature and Humidity sensors (Plate 1a and b), which were programmed to measure at 10 minutes sampling interval. Each of the sensors are shielded and well positioned in each pen. A stand-alone automated weather station was deployed outside the pen house which measured Temperature and Relative humidity parameters within the premises (Plate 1c). Data collected in the course of the trial includes; daily ambient temperature, humidity, feed intake, water intake, weight gain and computed feed conversion ratio. (a)

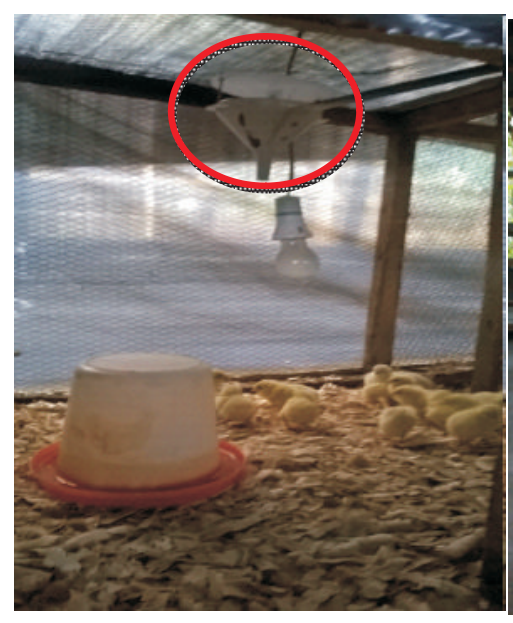

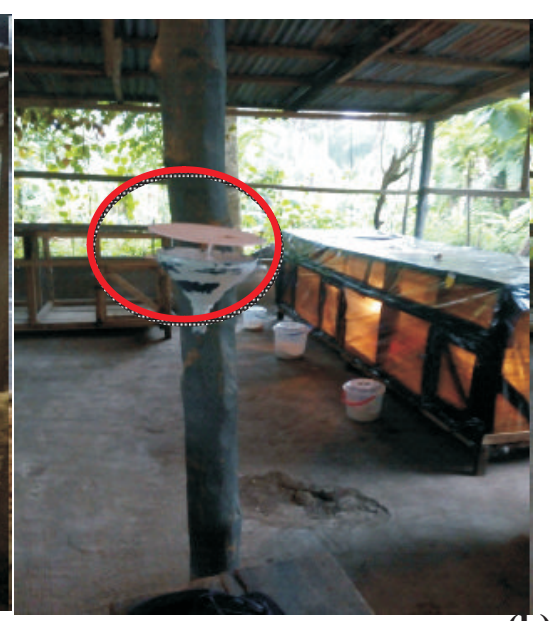




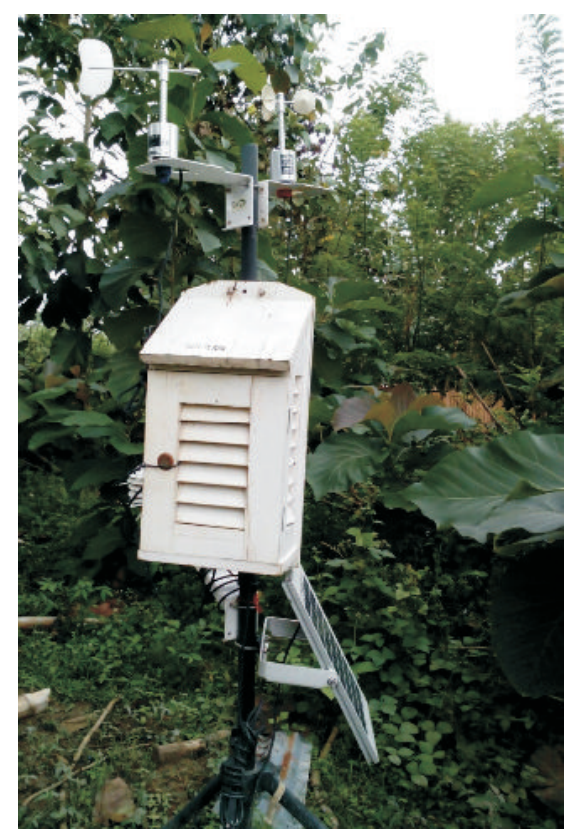

Plate 1: The pictures of the Maxims thermocron i-button Temperature and Humidity sensors (red circle) (a) inside the pen (b) within the poultry house and (c) a stand-alone Automatic Weather Station (AWS) outside.

\section{Statistical analysis}

The data from the experiment were analysed using descriptive statistics (mean), analysis of variance and regression analysis. When a significant $F$ statistics was noted, treatment means were separated using Duncan's Multiple Range Test (SAS Institute, 1987) A quantitative relationship between the weather and variations in the various performance parameters was analysed using correlation matrix described by Pearson Correlation (Pearson, 1990).

\section{Results and discussion}

Comparative patterns of weather parameters and performance at different broiler stocking densities

The variation in the weather variables in terms of their magnitude was observed at the broiler chicken environment relative to the three treatments (stocking densities; 5, 10 and 15 birds per $\mathrm{m}^{2}$ represented as S5, S10 and S15 respectively) over the period of eight weeks (between late May and early July) as presented in Figure 1a. Even though, the weekly mean temperature of the poultry house $\left(\mathrm{T}_{\mathrm{w}}\right)$ was warmer than that outside the poultry house (To) both the $T_{w}$ and $T_{0}$ had similar decreasing trends from the first week of observation. The fallen mean temperatures were at $23.01{ }^{\circ} \mathrm{C}$ occurring at week eight and $25.12^{\circ} \mathrm{C}$ at week five for $T_{0}$ and $T_{w}$, respectively. However, the mean temperatures of the poultry pens showed similar increasing trends from the first week to the third week with the peaks at $31.43^{\circ} \mathrm{C}$ for treatments $\mathrm{S} 5$ (5birds $\left./ \mathrm{m}^{2}\right), 29.84^{\circ} \mathrm{C}$ for $\mathrm{S} 10$ (10birds $/ \mathrm{m}^{2}$ ) and $31.80^{\circ} \mathrm{C}$ for $\mathrm{S} 15$ (15 birds $\left./ \mathrm{m}^{2}\right)$, and decreased thereafter. The increasing temperature could be associated with increasing body sizes and metabolic activities with the consequential heat loss through the skin and breathing. However, the temperature that peaked on week three confirmed the fact that broiler chickens had 


\section{Rearing environment and performance of broiler chicken under different stocking densities}

limited physiological capacity to control body temperature at the early age (1-4 weeks) (Maarten et al., 2015) and the decrease thereafter revealed their physiological coping capacity to control body temperature as they grow. Also, the differently peaked temperatures for the treatments could be attributed to the different stocking densities; showing that stocking densities is directly proportional to the temperature within the broiler pens. Therefore, increasing stocking densities could bring about increased ambient temperature (Dawkins et al., 2004). However, recorded mean temperatures were not too far from the $30^{\circ} \mathrm{C}$ crucial temperature for poultry, beyond which feed and energy intake declines to such an extent that birds are no longer able to compensate for it, thereby suffer rapid production decline and increase rate of mortality (Daghir, 2009).

Table 1 shows the trends and magnitude of change in temperature of the poultry pens. The negative sign indicates loss in temperature. It was found that the mean temperature gains occurred between weeks 1 and 2, 2 and 3 and 6 and 7 while mean temperature losses occurred between weeks $3-4,4-5$ and 7-8 in all the treatments. This confirms the tendency of broiler chicken to get rid of heat after about three weeks of age (Maarten et al., 2015). The table also shows that the highest magnitude of rise in mean temperature was found in treatment S5 $\left(3.46^{\circ} \mathrm{C}\right)$ between week one and two still confirm the report of Maarten et al., 2015; while the highest magnitude of loss in temperature was in treatment $\mathrm{S} 15\left(-4.21^{\circ} \mathrm{C}\right)$ between week 3 and 4 . A decrease in temperature of S5 was also observed between week 5 and 6 as the temperatures of S10 and S15 increased (Table 1). These fluctuations in temperature changes among the treatment pens could be attributed to various influences of stocking densities on broilers' welfare responses (dustbathing, preening, pecking and scratching of surfaces) with corresponding metabolic activities that resulted in difference in heat production among the treatments. Therefore, level of influence of stocking densities on birds' welfare and metabolic activities will dictate the magnitude of changes in the birds' immediate environment.

Moreover, weekly mean relative humidity (RH) showed large variations throughout the periods and for all the sample stations. It was observed that the environmental condition inside the poultry house was moister than the outside throughout the period. This could be as a result of condensation of broilers' respiratory and faecal moistures that particularly contributed to the atmospheric moisture inside the broiler house, hence, higher relative humidity. The peak of the mean relative humidity inside the poultry house (RHw) was observed at $91.5 \%$ on the sixth week while that of relative humidity outside the poultry house (RHo) was at $83.5 \%$ on week three (Figure 1b). The lower ambient temperatures in the treatment pens S5 and S10 was responsible for their being more humid than S15 from week one to four. This tends to show that appropriate ventilation is of necessity in the stocking of broiler chickens; because for broiler chickens, moisture removal is a very important method of getting rid of heat (Maarten et al., 2015). However, from week five to eight, $\mathrm{S} 10$ and S15 were moister than S5. This is an indication that impact of stocking densities becomes much more of concern when the chickens got older because of increase in body size and metabolic activities that culminated in much condensation of higher faecal and respiratory moistures. Hence, broiler chickens could be stocked at high density when their young but reducing their density 


\section{Asaniyan and Akinduro}

at higher ages. The maximum RHs were $86.5 \%$ on week $8,90.3 \%$ on week 6 , and $89.5 \%$ on week 6 for treatments S5, S10, and S15 respectively. Quantitatively, the atmosphere of the poultry pens became more humid in terms of increase in $\mathrm{RH}$ between weeks 4-5, 5-6, and 7-8, while less humid between weeks 1-2 and 6-7 (Table $2)$. The increased moist atmosphere between weeks 4-5 and 7-8 and decreased moist air between weeks 1-2 and 6-7 corresponds with the periods of mean temperature fall and rise respectively, which indicated that, as the temperature of the poultry pens increased, the $\mathrm{RH}$ decreased and vice versa. Table 2 shows that the highest magnitude of rise in mean $\mathrm{RH}$ was found in treatment S15 (16.98\%) between weeks 4 and 5, while the highest magnitude of decrease in $\mathrm{RH}$ also fell in treatment S15 (-5.52\%) between week 1-2. A decrease in RH of S10 was observed between weeks 2 and 3 as the RHs of S5 and S15 increased, and an inverse situation occurred between weeks 3 and 4 (Table 2). Generally, it was found that, as the environmental conditions outside and within the poultry house become cooler, the poultry pens get warmer depending on the number of chickens per pen. The change in the weather responses relative to the environmental conditions of the poultry house was as a result of the weather modification outcome of stocking densities.

(a)
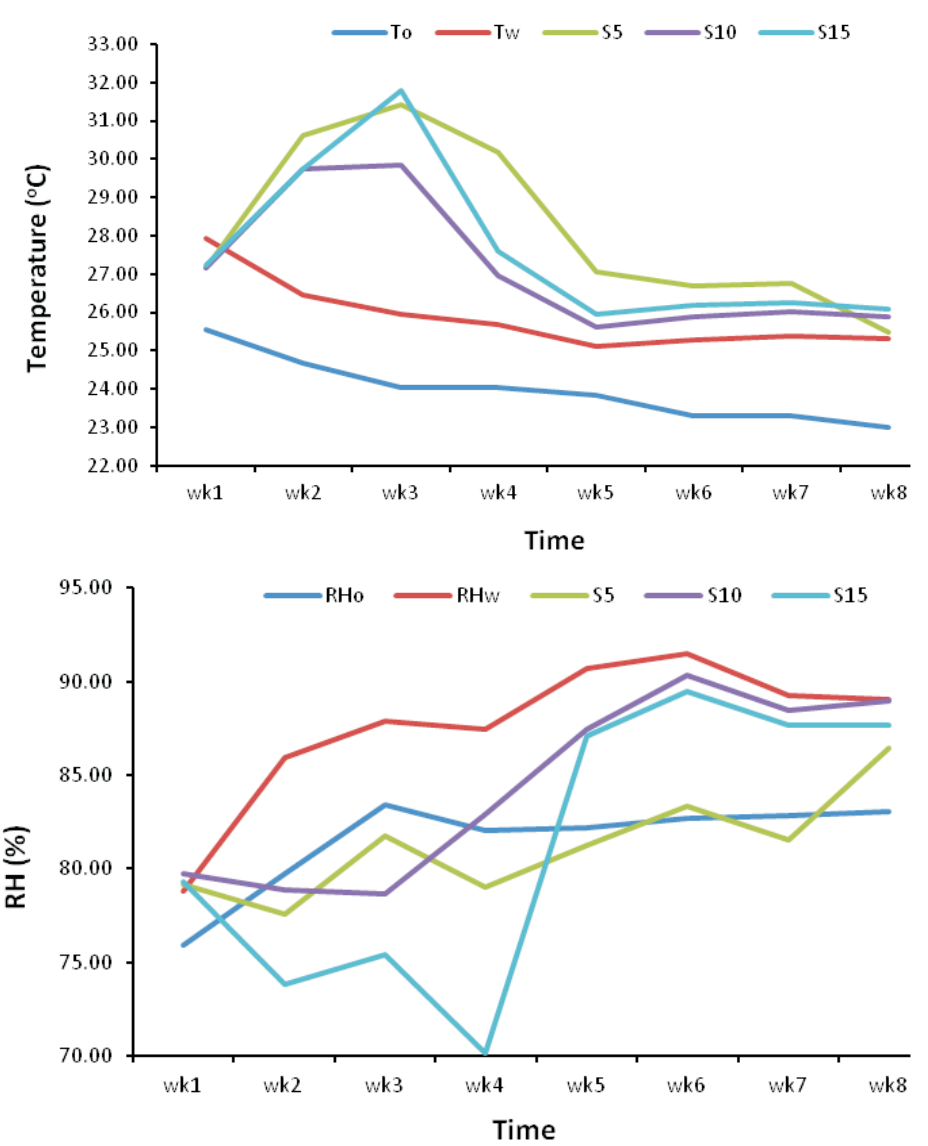

$\mathrm{S} 5=5 \operatorname{birds} / \mathrm{m}^{2} ; \mathrm{S} 10=10 \operatorname{birds} / \mathrm{m}^{2} ; \mathrm{S} 15=15 \operatorname{birds} / \mathrm{m}^{2}$

Figure 2: The pattern of (a) Temperature and (b) Relative Humidity at different environments within the experimental site 
Rearing environment and performance of broiler chicken under different stocking densities

Table 1: Trends and average magnitude of mean temperature $\left({ }^{\circ} \mathrm{C}\right)$ changes at different stocking densities from week 1 to 8

\begin{tabular}{cccccccc}
\hline & & & \multicolumn{5}{c}{ Weekly changes in temperature } \\
\hline Week & S5 & S10 & S15 & Week difference & S5 & S10 & S15 \\
\hline 1 & 27.15 & 27.15 & 27.22 & 1 & 0.00 & 0.00 & 0.00 \\
2 & 30.61 & 29.73 & 29.76 & $1-2$ & 3.46 & 2.58 & 2.54 \\
3 & 31.43 & 29.84 & 31.80 & $2-3$ & 0.82 & 0.11 & 2.04 \\
4 & 30.18 & 26.94 & 27.59 & $3-4$ & -1.25 & -2.90 & -4.21 \\
5 & 27.05 & 25.62 & 25.94 & $4-5$ & -3.13 & -1.32 & -1.65 \\
6 & 26.71 & 25.89 & 26.20 & $5-6$ & -0.34 & 0.27 & 0.26 \\
7 & 26.75 & 26.02 & 26.25 & $6-7$ & 0.04 & 0.13 & 0.05 \\
8 & 25.47 & 25.88 & 26.10 & $7-8$ & -1.28 & -0.14 & -0.15 \\
& & & & & & & \\
\end{tabular}

$\mathrm{S} 5=5 \operatorname{birds} / \mathrm{m}^{2} ; \mathrm{S} 10=10 \operatorname{birds} / \mathrm{m}^{2} ; \mathrm{S} 15=15 \operatorname{birds} / \mathrm{m}^{2}$

Table 2: Trends and average magnitude of mean humidity (\%) changes at different stocking densities from week 1 to 8

\begin{tabular}{cccccccc}
\hline & & & \multicolumn{5}{c}{ Weekly changes in humidity } \\
\hline Week & S5 & S10 & S15 & Week difference & S5 & S10 & S15 \\
\hline 1 & 79.13 & 79.73 & 79.34 & 1 & 0.00 & 0.00 & 0.00 \\
2 & 77.61 & 78.89 & 73.82 & $1-2$ & -1.52 & -0.84 & -5.52 \\
3 & 81.78 & 78.66 & 75.44 & $2-3$ & 4.17 & -0.23 & 1.62 \\
4 & 79.03 & 82.89 & 70.12 & $3-4$ & -2.75 & 4.23 & -5.32 \\
5 & 81.23 & 87.44 & 87.10 & $4-5$ & 2.20 & 4.55 & 16.98 \\
6 & 83.35 & 90.31 & 89.46 & $5-6$ & 2.12 & 2.87 & 2.36 \\
7 & 81.57 & 88.47 & 87.66 & $6-7$ & -1.78 & -1.84 & -1.80 \\
8 & 86.46 & 89.00 & 87.69 & $7-8$ & 4.89 & 0.53 & 0.03 \\
\hline S5 5 birds $/ \mathrm{m}^{2} ; \mathrm{S} 10=10$ birds $/ \mathrm{m}^{2} \cdot \mathrm{S} 15=15$ birds $/ \mathrm{m}$
\end{tabular}

$\mathrm{S} 5=5 \operatorname{birds} / \mathrm{m}^{2} ; \mathrm{S} 10=10 \operatorname{birds} / \mathrm{m}^{2} ; \mathrm{S} 15=15 \mathrm{birds} / \mathrm{m}$

The performance pattern of the broiler chickens in terms of the generic growth curve which is a function of weight gain (WG), the feed intake (FI), the water intake (WI) and the feed conversion ratio (FCR) was also analysed and the results are presented in Figures 2 and 3. Figure 2 shows an increasing trend in the rate of feed and water consumptions throughout the period of eight weeks and for all the treatments, except in week 6 which showed a reduction in the feed and water intakes, due to high temperature with low relative humidity. Comparatively, treatments S5 and S10 tend to consume more feeds and water than S15 especially from the age of four weeks to eight weeks in this study (Figure $3 a$ and $b$ ). The relative depth of weather modification within S15 must have subjected the chickens to non-fatal heat stress that resulted in relatively low water and feed consumptions. In absolute terms, the rise in the mean feed intake occurred at weeks 1-2, 2-3, 4-5, 6-7 and 7-8, while mean feed intake losses occurred between weeks 5-6 only in all the treatments (Table 3 ). Table 3 also shows that the highest magnitude of rise in feed intake was found in treatment S15 (653.08 g/bird/week) between week 67 , while the highest magnitude of decrease in feed intake also found in treatment S15 (458.55 ) between week 5-6. Increase in feed intake of S5 was also observed between week 3-4 as the feed intakes of S10 and S15 decreased (Table 3). Moreover, the rise in the mean water intake occurred between weeks 1-2, 2-3, and 4-5, while losses occurred only between weeks 3-4 in all the treatments (Table 4). Among all the treatments and throughout the study periods, the birds at S5 consumed more water (increased magnitude of 1.15) 


\section{Asaniyan and Akinduro}

between weeks 2-3, and less water (magnitude -0.76) between weeks 7-8, than S10 and S15. The high and low rates of water intake in $\mathrm{S} 5$ might be as a result of the warm moist atmospheric condition of the poultry pens and increased feed intake during this period respectively.
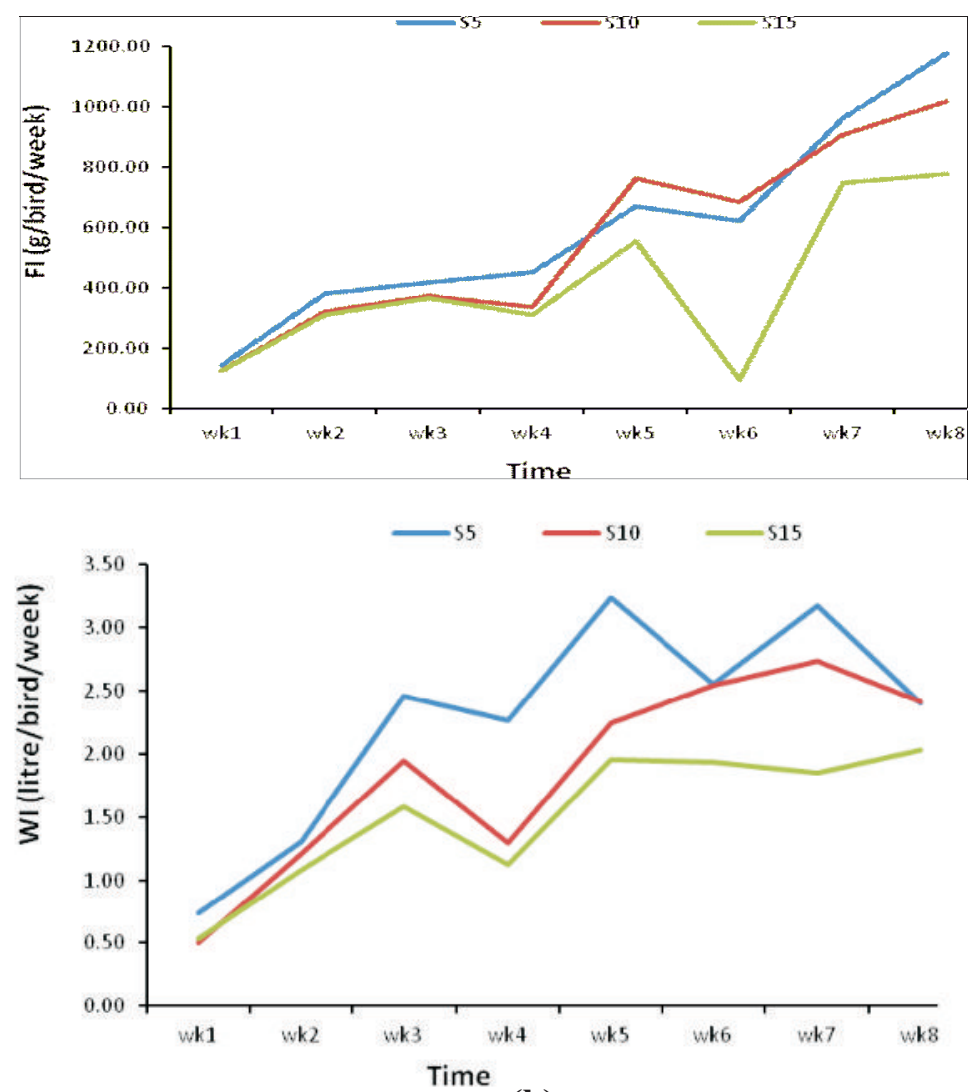

(b)

$\mathrm{S} 5=5 \operatorname{birds} / \mathrm{m}^{2} ; \mathrm{S} 10=10 \operatorname{birds} / \mathrm{m}^{2} ; \mathrm{S} 15=15 \operatorname{birds} / \mathrm{m}^{2}$

Figure 3: The pattern of performance parameters of broiler chickens (a) Feed Intake (FI) and (b) Water Intake (WI) at different stocking densities.

Table 3: Trends and average magnitude of feed intake ( $\mathrm{g} / \mathrm{bird} / \mathrm{week})$ at different stocking densities from week 1 to 8

\begin{tabular}{cccccccc}
\hline & & & \multicolumn{5}{c}{ Weekly changes in feed intake } \\
\hline Week & S5 & S10 & S15 & Week difference & S5 & S10 & S15 \\
\hline 1 & 143.33 & 126.67 & 126.12 & 1 & 0.00 & 0.00 & 0.00 \\
2 & 380.83 & 321.67 & 311.46 & $1-2$ & 237.50 & 195.00 & 185.34 \\
3 & 417.50 & 372.96 & 368.46 & $2-3$ & 36.67 & 51.29 & 57.00 \\
4 & 452.50 & 339.26 & 313.11 & $3-4$ & 35.00 & -33.70 & -55.35 \\
5 & 669.72 & 763.52 & 554.62 & $4-5$ & 217.22 & 424.26 & 241.51 \\
6 & 621.11 & 685.56 & 96.07 & $5-6$ & -48.61 & -77.96 & -458.55 \\
7 & 963.61 & 909.63 & 749.15 & $6-7$ & 342.50 & 224.07 & 653.08 \\
8 & 1179.17 & 1018.96 & 778.97 & $7-8$ & 215.56 & 109.33 & 29.80 \\
\hline
\end{tabular}

$\mathrm{S} 5=5 \mathrm{birds} / \mathrm{m}^{2} ; \mathrm{S} 10=10 \mathrm{birds} / \mathrm{m}^{2} ; \mathrm{S} 15=15 \mathrm{birds} / \mathrm{m}^{2}$ 
Rearing environment and performance of broiler chicken under different stocking densities

Table 4: Trends and average magnitude of water intake (litre/bird/week) at different stocking densities from week 1 to 8

\begin{tabular}{cccccccc}
\hline & & & \multicolumn{5}{c}{ Weekly changes in water intake } \\
\hline Week & S5 & S10 & S15 & Week difference & S5 & S10 & S15 \\
\hline 1 & 0.74 & 0.50 & 0.53 & 1 & 0.00 & 0.00 & 0.00 \\
2 & 1.30 & 1.21 & 1.08 & $1-2$ & 0.56 & 0.71 & 0.55 \\
3 & 2.46 & 1.94 & 1.58 & $2-3$ & 1.15 & 0.73 & 0.50 \\
4 & 2.26 & 1.30 & 1.12 & $3-4$ & -0.19 & -0.65 & -0.46 \\
5 & 3.23 & 2.25 & 1.96 & $4-5$ & 0.97 & 0.95 & 0.84 \\
6 & 2.56 & 2.54 & 1.93 & $5-6$ & -0.67 & 0.29 & -0.02 \\
7 & 3.17 & 2.74 & 1.85 & $6-7$ & 0.61 & 0.19 & -0.09 \\
8 & 2.41 & 2.41 & 2.03 & $7-8$ & -0.76 & -0.32 & 0.18 \\
\hline
\end{tabular}

$\mathrm{S} 5=5$ birds $/ \mathrm{m}^{2} ; \mathrm{S} 10=10$ birds $/ \mathrm{m}^{2} ; \mathrm{S} 15=15 \mathrm{birds} / \mathrm{m}^{2}$

Consequently, the feed conversion ratio (FCR) of the broiler chickens revealed a decreasing pattern from week one, which indicates that the chickens in all the treatments were more efficient in using up the feed supplied (Figure 4a). However, a magnitude increase in the feed utilization at 0.08 FCR was observed in S15 on week 6. Comparatively, FCR showed similar change in magnitude with feed intake which indicates that as the feed intake reduces, FCR also decreased thus, the birds become more efficient in using up the feed consumed for body metabolism (Table 5). As it is typical of all animals, the broilers experienced a period of a rapid growth early in their development (Figure 3b). This is then followed by a slow rate of growth from the age seven weeks as more feed is used in maintaining the already existing body structure. As a result, feed utilization is much better in the early weeks of broiler production and then declines with increased target market weight. The weight gain from the fourth week tends to be higher in S5 and S10 than in S15 due to relative influence of stocking density that promotes different metabolic activities among the treatments as a result of welfare differences (Beloor $e t$ al., 2010). The trend and magnitude of weight gain in the birds showed increasing order in all the treatments and throughout the period of study regardless of the change in the weather and other performance parameters (Table 6). The highest value change in weight gain was observed between weeks 6-7 among the treatments, but birds at S5 tend to grow to be the best followed by S10 and S15 had the lowest weight gain. This could be associated with high temperature and low humidity that affected feed utilization negatively in S15 as a result of high stocking density. It implies that high stocking density could impair weight gain in broiler chicken.

(a)

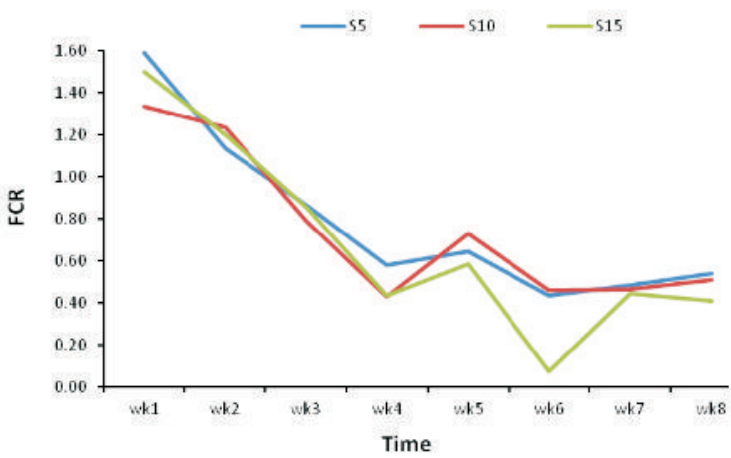




\section{Asaniyan and Akinduro}

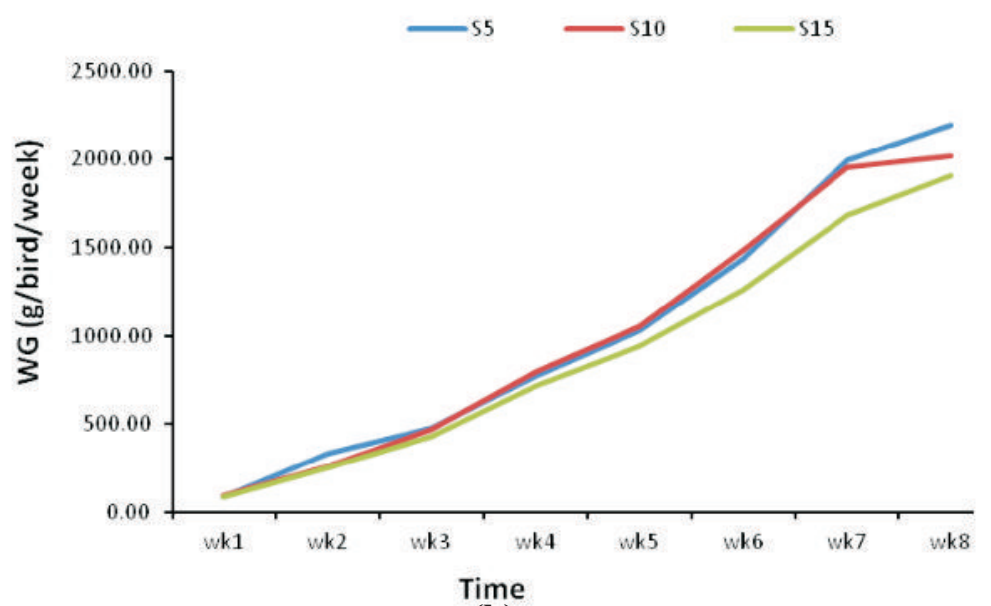

(b)

$\mathrm{S} 5=5 \mathrm{birds} / \mathrm{m}^{2} ; \mathrm{S} 10=10 \mathrm{birds} / \mathrm{m}^{2} ; \mathrm{S} 15=15$ birds $/ \mathrm{m}^{2}$

Figure 4: The pattern of performance parameters of broiler chickens: (a) Feed Conversion Ratio (FCR) and; (b) Weight Gain (WG) at different stocking densities.

Table 5: Trends and average magnitude of feed conversion ratio (FCR) at different stocking densities from week 1 to 8

\begin{tabular}{cccccccc}
\hline & & & \multicolumn{5}{c}{ Weekly changes in FCR } \\
\hline Week & S5 & S10 & S15 & Week difference & S5 & S10 & S15 \\
\hline 1 & 1.59 & 1.33 & 1.50 & 1 & 0.00 & 0.00 & 0.00 \\
2 & 1.14 & 1.24 & 1.20 & $1-2$ & -0.45 & -0.10 & -0.30 \\
3 & 0.87 & 0.79 & 0.86 & $2-3$ & -0.27 & -0.45 & -0.34 \\
4 & 0.58 & 0.43 & 0.44 & $3-4$ & -0.29 & -0.36 & -0.42 \\
5 & 0.65 & 0.73 & 0.59 & $4-5$ & 0.07 & 0.30 & 0.15 \\
6 & 0.44 & 0.46 & 0.08 & $5-6$ & -0.21 & -0.27 & -0.51 \\
7 & 0.48 & 0.47 & 0.45 & $6-7$ & 0.05 & 0.01 & 0.37 \\
8 & 0.54 & 0.51 & 0.41 & $7-8$ & 0.06 & 0.04 & -0.04 \\
\hline
\end{tabular}

$\mathrm{S} 5=5$ birds $/ \mathrm{m}^{2} ; \mathrm{S} 10=10$ birds $/ \mathrm{m}^{2} ; \mathrm{S} 15=15$ birds $/ \mathrm{m}^{2}$

Table 6: Trends and average magnitude of weight gain (g/bird/day) at different stocking densities from week 1 to 8

\begin{tabular}{cccccccc}
\hline & & & & \multicolumn{5}{c}{ Weekly changes in weight gain } \\
\hline Week & S5 & S10 & S15 & Week difference & S5 & S10 & S15 \\
\hline 1 & 90.00 & 95.00 & 84.19 & 1 & 0.00 & 0.00 & 0.00 \\
2 & 335.56 & 260.00 & 258.46 & $1-2$ & 245.56 & 165.00 & 174.28 \\
3 & 480.56 & 470.74 & 426.84 & $2-3$ & 145.00 & 210.74 & 168.37 \\
4 & 777.22 & 795.37 & 716.24 & $3-4$ & 296.67 & 324.63 & 289.40 \\
5 & 1030.83 & 1050.19 & 944.62 & $4-5$ & 253.61 & 254.81 & 228.38 \\
6 & 1435.56 & 1486.85 & 1259.66 & $5-6$ & 404.72 & 436.67 & 315.04 \\
7 & 1997.78 & 1956.85 & 1687.09 & $6-7$ & 562.22 & 470.00 & 427.43 \\
8 & 2197.78 & 2018.52 & 1907.44 & $7-8$ & 200.00 & 61.67 & 220.34 \\
\hline
\end{tabular}

$\mathrm{S} 5=5 \mathrm{birds} / \mathrm{m}^{2} ; \mathrm{S} 10=10 \mathrm{birds} / \mathrm{m}^{2} ; \mathrm{S} 15=15 \mathrm{birds} / \mathrm{m}$ 
Influence of stocking density on the temperature and humidity in the broiler chicken pens

The responses of weather parameters observed in the broiler chicken pens under the three stocking densities $(5,10$ and 15 birds $/ \mathrm{m}^{2}$ tagged $\mathrm{S} 5, \mathrm{~S} 10$ and $\mathrm{S} 15$ respectively) of broiler chickens are presented in Table 1.

Table 7: Weather parameters of poultry pens at three different stocking densities from week 1 to 8

\begin{tabular}{ccccccc}
\hline & \multicolumn{3}{c}{ Temperature } & \multicolumn{3}{c}{ Relative Humidity } \\
\cline { 2 - 7 } Week & S5 & S10 & S15 & S5 & S10 & S15 \\
\hline 1 & $27.15 \pm 0.193$ & $27.15 \pm 0.198$ & $27.22 \pm 0.196$ & $79.5 \pm 0.801$ & $79.4 \pm 0.826$ & $79.3 \pm 0.814$ \\
2 & $30.61 \pm 0.318$ & $29.73 \pm 0.278$ & $29.76 \pm 0.279$ & $74.4 \pm 0.699$ & $77.8 \pm 0.564$ & $78.2 \pm 0.595$ \\
3 & $29.84 \pm 0.266$ & $31.79 \pm 0.360$ & $76.9 \pm 0.932$ & $83.0 \pm 0.642$ & $75.9 \pm 0.998$ & $31.43 \pm 0.353$ \\
4 & $30.18 \pm 0.213$ & $26.94 \pm 0.178$ & $27.59 \pm 0.180$ & $69.8 \pm 0.733$ & $82.6 \pm 0.670$ & $79.7 \pm 0.655$ \\
5 & $27.05 \pm 0.138$ & $25.62 \pm 0.125$ & $25.94 \pm 0.125$ & $80.9 \pm 0.512$ & $88.3 \pm 0.515$ & $86.7 \pm 0.475$ \\
6 & $26.71 \pm 0.163$ & $25.88 \pm 0.132$ & $26.19 \pm 0.135$ & $84.5 \pm 0.618$ & $90.2 \pm 0.561$ & $88.5 \pm 0.518$ \\
7 & $26.75 \pm 0.144$ & $26.02 \pm 0.138$ & $26.25 \pm 0.137$ & $82.9 \pm 0.663$ & $88.3 \pm 0.715$ & $86.4 \pm 0.644$ \\
8 & $25.47 \pm 0.136$ & $25.88 \pm 0.136$ & $26.09 \pm 0.138$ & $87.8 \pm 0.639^{\mathrm{a}}$ & $88.5 \pm 0.665^{\mathrm{b}}$ & $86.8 \pm 0.598^{\mathrm{ab}}$ \\
\hline Mean+ SEM & \multicolumn{3}{c}{$\mathrm{S} 5=5$ birds $/ \mathrm{m}^{2} ; \mathrm{S} 10=10$ birds $/ \mathrm{m}^{2} ; \mathrm{S} 15=15$ birds $/ \mathrm{m}^{2}$} & & \\
& \multicolumn{3}{c}{ Means with different superscripts in the same row are significantly different $(\mathrm{P}<0.05)}$.
\end{tabular}

The overview of the responses revealed no significant $(\mathrm{P}>0.05)$ influence of the stocking densities on weekly mean temperature and relative humidity of the poultry pens throughout the period of study except in week 8 for relative humidity. The mean temperatures of the broiler chicken pens showed similar increasing trends from the first week to the third week with the peaks at $31.43 \pm 0.353^{\circ} \mathrm{C}$ for treatments $\mathrm{S} 5$ $\left(5 \mathrm{birds} / \mathrm{m}^{2}\right), \quad 29.84 \pm 0.266^{\circ} \mathrm{C}$ for $\mathrm{S} 10$ (10birds $/ \mathrm{m}^{2}$ ) and $31.79 \pm 0.360^{\circ} \mathrm{C}$ for $\mathrm{S} 15$ $\left(15 \mathrm{birds} / \mathrm{m}^{2}\right)$, and decreased thereafter. The increasing temperatures that got to their peak at week three for the different treatments was as a result of increasing body sizes of the broiler chicks that enhance increasing metabolic activities with the corresponding heat loss through the skin and breathing. However, the temperature that peaked on week three and decreased thereafter confirmed the fact that broiler chickens had limited physiological capacity to control body temperature at the early age (1-4 weeks) as reported by Maarten et al. (2015). Also, the differently peaked temperatures for the treatments could be attributed to the different stocking densities; showing that stocking densities is directly proportional to the temperature within the broiler pens. Therefore, increasing stocking densities could bring about increased ambient temperature according to the findings of Dawkins et al. (2004). However, recorded mean temperatures were not too far from the $30^{\circ} \mathrm{C}$ crucial temperature for poultry, beyond which feed and energy intake declines to such an extent that birds are no longer able to compensate for it, thereby suffer rapid production decline and increase rate of mortality (Daghir, 2009).

This tends to show that the birds experienced similar ambient atmospheric condition throughout the period irrespective of the different stocking densities. However, the significant $(\mathrm{P}<0.05)$ influence of the stocking density on the relative humidity among the treatments at the eighth week could be jointly associated with the relative differences in temperature at week 8 and the age related increase in metabolic activities that yielded more respiratory and faecal 
moistures that contributed into atmospheric moisture within the pens. Fortunately, mortality was not recorded throughout the duration of this study. This could be an indication that the weather conditions within and outside the broiler house during the period of the study (between late May and early July) had contributed favourably (good ventilation) to the inability of the stocking densities to influence the weather situation within the broiler pens significantly to the detriment of the broilers' welfare. This corroborated the report of Dawkins et al., 2004 that high environmental quality is far more important than density per se in maintaining good health, performance and welfare of broiler chickens. Therefore, irrespective of stocking density levels, adequate ventilation has the mediating potential against the fatality of weather modification in the broiler pens.

Quantitative Relationship between weather and broiler performance parameters

The quantitative assessment over the entire eight-week study period is presented in Figure 5. The highest positive correlation among the performance parameters was found between the feed intake (FI) and weight gain (WG) for treatments S5 (5 birds $\left./ \mathrm{m}^{2}\right)$ and S10 (10 birds $\left./ \mathrm{m}^{2}\right)$ and water intake (WI) and WG for S15 (15 birds $\left./ \mathrm{m}^{2}\right)$, these are indications that increase in feed intake leads to increase in muscle growth of birds and vice versa under treatments S5 and S10 while the increase water intake resulted in the weight gain of the birds and vice versa in treatment S15. The negative correlation was between WI and feed conversion ratio (FCR) for $\mathrm{S} 5$ and $\mathrm{S} 15$ and FCR and WG for S10. This shows that increase in water intake brings about reduction in FCR in terms of magnitude in treatments S5 and S15 while magnitude reduction in FCR resulted in the increase of
WG for birds in treatment S10. Therefore, water intake promoted efficient use of feed in treatments S5 and S15 while weight gain principally indicated the efficient use of feed in treatment S10. For weather parameters, the highest positive correlation was between the temperature outside the broiler house (To) and the temperature inside (Tw) while negative correlation was between Tw and relative humidity inside the broiler house (RHw) across the treatments. The implication is that the increase in outside temperature directly increased the inside temperature of the broiler house while the inside temperature had inverse influence on the relative humidity within the broiler house in relation to all the treatments. Relating the weather and performance parameters for the entire study period for treatment $\mathrm{S}_{5}$, it was found that FCR has the best positive $(r=0.96)$ and negative $(r=0.93)$ relationships with $\mathrm{Tw}$ and $\mathrm{RHw}$, respectively (Figure 4). That is FCR increases with increasing temperature within the broiler house while the relative humidity within the house inversely influenced the FCR value. Therefore, temperature fluctuation within the house influenced how efficient the feed was used while decreasing relative humidity within the house negatively affected the efficient use of feed by the birds under treatment $\mathrm{S}_{5}$. This tends to reveal that ambient temperature had more influence on the broiler performance than the relative humidity under treatment $\mathrm{S}_{5}$. In treatment $\mathrm{S}_{10}$, WG had the best positive correlation $(\mathrm{r}=0.91)$ with $\mathrm{RH}$ of the pens, and the best negative relationship $(\mathrm{r}=0.94)$ was found between To and WI; an indication that WG increased as the relative humidity within the pen increases and vice versa while the outside temperature had inverse influence on the water consumption rate of the birds under treatment $\mathrm{S}_{10}$ (low water atmospheric 


\section{Rearing environment and performance of broiler chicken under different stocking densities}

temperature supports water intake under a stocking density of $10 \mathrm{birds} / \mathrm{m}^{2}$ ). This has shown that ambient condition of broiler chickens affects weight gain and other performance parameters than the whole environment (Ferket and Gernat, 2003; Dawkins et al., 2004). Treatment $\mathrm{S}_{15}$ shows that FCR and WI had the best positive correlation $(\mathrm{r}=0.91)$ with To and RHw respectively and the best negative correlation $(\mathrm{r}=0.93)$ between WI and To. This reveals that FCR and WI were directly influenced by the outside temperature of the broiler house and relative humidity within the broiler house respectively with outside temperature having inverse influence on water intake of the broiler chickens under the treatment $\mathrm{S}_{15}$. Generally, performance parameters were positively correlated with all the RH components and negatively correlated with temperature components in all the treatments except for FCR which positively correlated with temperature components in treatment $\mathrm{S}_{10}$ (Figure 4). Meaning that overall performance of the birds in all the treatments was influenced directly by all the relative humidity components with inverse influence of temperature (decreasing temperature) components considered in this study.
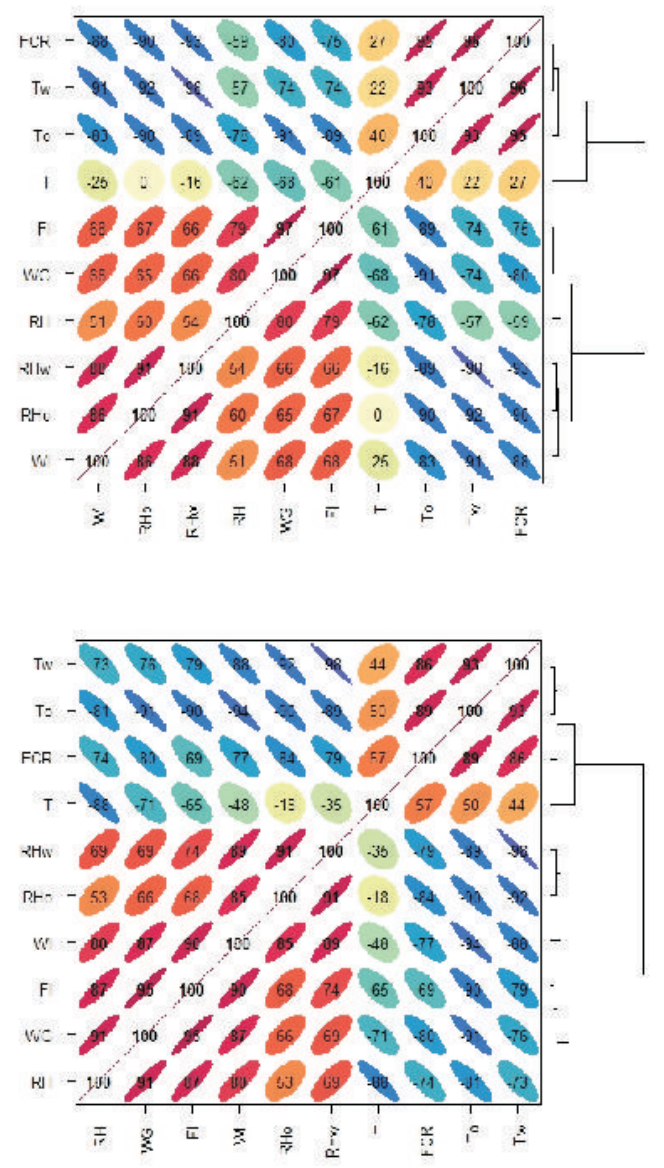


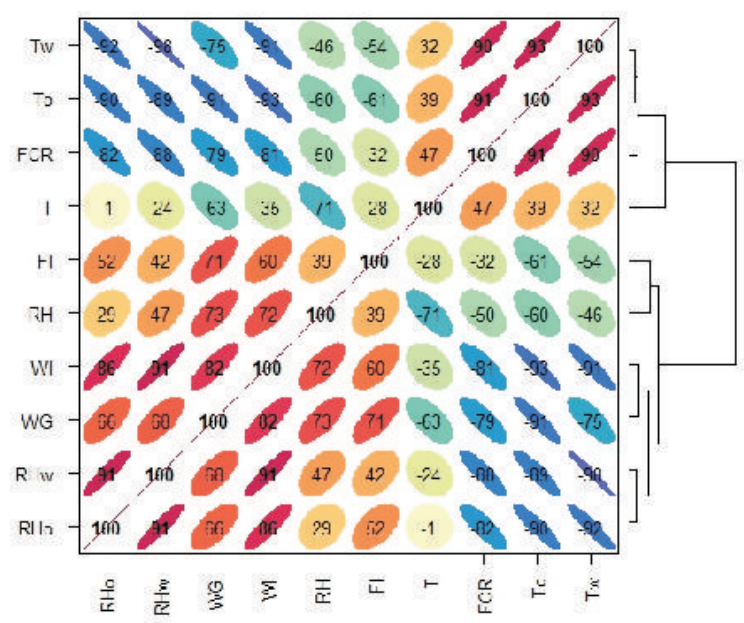

$\mathrm{Tw}=$ Temperature inside the poultry house; To = Temperature outside the poultry house; $\mathrm{RHw}=$ Relative humidity inside the poultry house; $\mathrm{RHo}=$ Relative humidity outside the poultry house; FCR = Feed conversion ratio; WI =Water intake; FI = Feed intake; $\mathrm{RH}=$ Relative humidity of the pen; $\mathrm{T}=$ Temperature of the pen

Figure 4: Correlations among performance and weather parameters for $S_{5}$ (top) $S_{10}$ (middle) and $S_{15}$ (bottom) throughout 8 weeks of the study period

\section{Conclusion}

The synergy among the weather and performance parameters in bringing about growth of the birds diminishes as the stocking density increases. The stocking densities virtually had no significant influence on the weekly mean temperature and relative humidity in the broiler chicken pens. However, the environmental conditions outside and within the poultry house resulted in weather modification outcome of warmer pens in relation to the number of chickens per pen.

Ambient condition of broiler chicken affects weight gain and other performance parameters than the whole environment. The broiler yields (weight gain) were principally influenced by feed intake and the ambient temperature throughout the duration of the study. Water consumption of broiler chicken was jointly influenced by feed intake, age and weather conditions within the pens especially temperature fluctuations. Increase in water intake brings about reduction in FCR in terms of magnitude in stocking densities 5 birds $/ \mathrm{m}^{2}$ and $15 \mathrm{birds} / \mathrm{m}^{2}$ while magnitude reduction in FCR resulted in the increase of weight gain for birds in stocking density 10 birds $/ \mathrm{m}^{2}$.

\section{Recommendation}

Broiler chickens could be reared for 8 weeks without compromising their optimum performance and wellbeing under any of these stocking densities and similar weather situation; but where land is adequate, better welfare under 5 birds $/ \mathrm{m}^{2}$ will be realized. However, irrespective of stocking density levels, fatality of weather modification within rearing environment could be prevented through uncompromised adequate ventilation. 


\section{References}

Asaniyan, E. K. and Agbede, J. O. 2012. Potentials of Sand as Litter Material instead of Wood Shavings in Broiler Enterprise. In: Building a Non-Oil Export Based Economy for Nigeria: The Potential of Value-Added Products from Agricultural Residues. (Ed. Simeon O. Jekayinfa) Göttingen: Cuvillier, 2012, p. $229-240$.

Bannor, T. T. and Ogunsan, E. A. 1987. The effect of environmental temperature on intensive poultry in Sokoto State of Nigeria. Bulletin of Animal Health and Production in Africa. 1987; 35:39-45.

Beloor, J., Kang, H. K., Kim, Y. J., Subramani, V. K., Jang, I. S., Sohn, S. H. and Moon, Y. S. 2010. The effect of stocking density on stress related genes and telomeric length in broiler chickens. Asian Aust. J. Anim. Sci. 23:437-443.

Bessei, W. 2006. Welfare of broilers: A review, Worlds Poult. Sci. J., 62: 455466

Bianca, W. 1976. The significance of meteorology in animal production. International Journal of

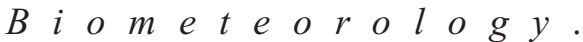
1976;20(2):139-156.

Daghir, N. J. 2009. Nutritional Strategies to Reduce Heat Stress in Broilers and Broiler Breeders, Lohmann Information, Vol. 44, No.1 (April 2009) pp. 6-15. ISSN: 1617-2906

Dawkins, M. S., Donnelly, C. A. and Jones, T. A. 2004. "Chicken welfare is influenced more by housing conditions than by stocking density." Nature 427:342-344.

Egbunike, G. N. 1979. The relative importance of dry- and wet-bulb temperatures in the thermorespiratory function in the chicken. Zentralblatt fur Veterinarmedizin. Reihe A. 1979;
26(7):573-579.

Estevez, I. 2007. Density allowances for broilers: where to set the limits" Poultry Science 86:1265-1272.

Jones, T. A., Donnelly, C. A., and Stamp Dawkins, M. 2005. Environmental and management factors affecting the welfare of chickens on commercial farms in the United Kingdom and Denmark stocked at five densities. Poultry Science 84: 1155-1165.

Maarten de, G., Koos van, M., Kristof van M., and Ellen van't, V. 2015. Broiler signals, A practical Guide to Broiler Focused Management. 120 pp. Roodbont Agricultural Publishers B.V. The Netherlands.

McNadabb, F. M. A. and King, D. B. 1993. "Thyroid hormone effect on growth, development and metabolism in vertebrates," Zoological Science, vol. 10, pp. 873-885, 1993.

Oladele, S. B., Ogundipe, S., Ayo, J. O. and Esievo, K. A. N. 2003. Seasonal and species variations in erythrocyte osmotic fragility of indigeneous poultry species in Zaria, Northern Guinea Savannah zone of Nigeria. Bulletin of Animal Health and Production in Africa. 2003 ; 51:204-214.

Pawan, K. V., Yashwant, S., Rajinder, R. and Jitender, K. 2012. Stress Biomarkers in Vanaraja Chicken Maintained Under Various Rearing Systems. Journal of Advanced Veterinary Research Volume 2 (2012) 5-8.

Plyaschenko, S. I. and Sidorov, V. T. 1987. Stresses in farm animals. Agropromizdat, Moscow. 1987:192 pages. (Rus).

Rama Rao, S. V., Raju, M. V. L. N., Panda, A. K., Poonam, N. S., Moorthy, O. K., Srilatha, T. and Shvam 2011. Performance, carcass 


\section{Asaniyan and Akinduro}

variables and immune responses in commercial broiler chicks fed graded concentrations of threonine in diet containing sub-optimal levels of protein. Animal Feed Science and Technology 169 (3-4), 218-223, 2011.

Sahin, N., Sahin, K. and Küçük, O. 2001. Effects of vitamin $\mathrm{E}$ and vitamin $\mathrm{A}$ supplementation on performance, thyroid status and serum concentrations of some metabolites and minerals in broilers reared under heat stress $\left(32^{\circ} \mathrm{C}\right)$ Veterinarni Medicina. 2001;46(11-12):286-292.
SAS Institute Inc. 1987. SAS/STATTM Guide for Personal Computers. Version 6, SAS Institute Inc. Cary.

SCAHAW (Scientific Committee on Animal Health and Animal Welfare), 2000. The Welfare of Chickens Kept for Meat Production (Broilers). European Commission, Health and Consumer Protection Directorate-General. 38:183-189.

Received: $17^{\text {th }}$ August, 2020 Accepted: $20^{\text {th }}$ December, 2020 